\title{
PENGENALAN APLIKASI EDUKASI PEMROGRAMAN KOMPUTER SCRATCH KEPADA SISWA KELAS IV SEKOLAH DASAR NEGERI MODEL MATARAM
}

\author{
Ida Bagus Fery Citarsa', I Nyoman Wahyu Satiawan', I Made Budi Suksmadana1, \\ I Ketut Wiryajati' ${ }^{1}$, Sabar Nababan ${ }^{1}$ \\ e-mail: ferycitarsa@unram.ac.id \\ ${ }^{1}$ Teknik Elektro, Universitas Mataram, Jl. Majapahit No. 62 Mataram
}

\begin{tabular}{ccc}
\hline Article history: Received: 29 Januari 2021 & Revised: 11 Februari 2021 & Accepted: 14 Februari 2021 \\
Corresponding author: I B fery Citarsa, Jurusan Teknik Elektro,Universitas Mataram, Email: ferycitarsa@unram.ac.id &
\end{tabular}

\section{ABSTRAK}

Mengajar teori pemrograman kepada anak-anak memiliki beberapa kesulitan. Dia membutuhkan logika berpikir yang cukup tinggi, dan metode pembelajaran yang digunakan umumnya kurang menarik bagi anak-anak. Hal ini menyulitkan usaha untuk mengubah kebiasaan anak-anak dari pengguna pasif menjadi pengguna aktif teknologi komputer. Untuk mengatasi masalah tersebut, tim yang beranggotakan staf pengajar Jurusan Teknik Elektro Fakultas Teknik Universitas Mataram telah melaksanakan suatu kegiatan pengabdian kepada Siswa Kelas IV Sekolah Dasar Negeri Model Mataram berupa pembelajaran teori pemrograman khusus menggunakan aplikasi edukasi Scratchyang mudah dipahami dan menyenangkan bagi anak-anak. Berdasarkan hasil evaluasi kegiatan pengabdian kepada masyarakat yang telah dilaksanakan diketahui bahwa penyuluhan ini telah memberikan pengetahuan kepada siswa mengenai teori pemrograman komputer menggunakan perangkat lunak Scratch. Berdasarkan penilaian terhadap hasil kreasi para siswa diketahui bahwa para siswa tersebut telah cukup memahami mengenai teori pemrograman komputer menggunakan aplikasi edukasi Scratch.

Kata kunci : pembelajaran, teori pemrograman, menarik, anak-anak

\section{PENDAHULUAN}

Kemajuan teknologi menghasilkan kondisi dimana anak-anak sekarang dikelilingi oleh teknologi. Mereka adalah para ahli dalam mengkonsumsi atau menggunakan teknologi ini, tetapi mereka tidak memahami dan menghargai apalagi memiliki kemampuan untuk membuat aplikasi. Ini menyebabkan mereka akan menjadi peserta pasif dari perkembangan teknologi dan bukan menjadi peserta aktif atau "pencipta," teknologi. Belajar teori pemrograman memungkinkan bagi anak-anak untuk meningkatkan tingkat kreativitas mereka agar mereka memiliki kegiatan yang positif dalam memanfaatkan teknologi sekaligus memberikan kontrol bagi orang tua atas dunia mereka terkait dengan penggunaan teknologi. Kemampuan kognitif anak-anak dapat dilkembangkan melalui pembelajaran komputer yaitu dengan melatih kemampuan mengingat, melakukan pemecahan masalah[1]. IImu komputer memberi kemampuan untuk mengatur dan memanipulasi data pada berbagai bidang kehidupan. Dalam dunia sekarang ini, keterampilan pemrograman komputer adalah alat inovasi untuk menciptakan banyak hal yang dapat bermanfaat baik secara sosial maupun ekonomis.

Pengenalan pengetahuan pemrograman bagi siswa sekolah dasar dan menengah sangat diperlukan untuk meningkatkan cara berpikir dan kreatifitas anak [2]. Untuk dapat melakukan pemrograman, diperlukan keterampilan dalam algoritma, logika, analisis, bahasa pemrograman, dan di banyak kasus, pengetahuan-pengetahuan lain seperti matematika. Pembelajaran teori pemrograman sebaiknya dilakukan sedini mungkin yaitu kepada siswa agar ke depannya mereka dapat lebih dini lagi bisa mengembangkan teknologi. Tapi sangat sulit membayangkan jika kita ingin mengarahkan anak-anak untuk mempelajari pemrograman yangtidak luput dari penulisan kode program. Hal ini terkait dengan logika berpikir anak-anak yang masih belum cukup untuk memahami logika penulisan.

Namun kendala di atas masih dapat dicarikan solusi pemecahannya. Proses pembelajaran teori pemrograman dapat dilakukan dengan memahami karakteristik anak-anak usia dini yang umumnya memiliki kegemaran yang sama, yaitu bermain. Kegemaran bermain mereka dapat digunakan sebagai metode untuk mengajarkan mereka sesuatu yang masih dianggap sulit bahkan mustahil. Memang hal ini bukan cara yang mudah, harus optimis bisa mengajarkan 
anak-anak kemampuan pemrograman sejak berusia dini tepatnya setelah mereka bisa membaca.

Sebelum mulai menerapkan hal yang cukup sulit ini kepada anak-anak, sebaiknya dirubah sudut pandang dan konsentrasi kepada hasil akhir tanpa mengkhawatirkan hal-hal berikut ini:

1. Siswa sekolah dasar belum mampu belajar kode pemrograman.

2. Kurikulum teori pemrograman belum diterapkan pada tingkat Sekolah Dasar.

3. Orang tua atau guru tidak memiliki kemampuan memadai untuk mengajari anakanak mengenai teknik pemrograman.

Pembelajaran teori pemrograman kepada anak-anak secara umum memiliki beberapa permasalahan yaitu :

1. Pembelajaran teori pemrograman membutuhkan logika berpikir yang cukup tinggi sehingga anak-anak kesulitan untuk memahami.

2. Pembelajaran teori pemrograman umumnya menggunakan metode pembelajaran yang kurang menarik bagi anak-anak

3. Pendidik tingkat SD umumnya belum memiliki kemampuan memadai untuk mengajari anak-anak mengenai teori pemrograman.

Permasalahan-permasalahan tersebut menyebabkan usaha pembelajaran teori pemrograman kepada anak-anak menjadi tidak mudah. Hal ini akan menyulitkan usaha untuk mengubah kebiasaan anak-anak dari pengguna pasif teknologi komputer menjadi pengguna aktif teknologi komputer.Permasalahan-permasalahan tersebut akan berusaha diatasi dengan adanya pembelajaran teori pemrograman khusus menggunakan aplikasi edukasi yang mudah dipahami dan menyenangkan bagi anak-anak dalam hal ini khususnya anak SD kelas IV.

Aplikasi edukasi anak dapat digunakan untuk mengajarkan konsep dan bahasa pemrograman, berpikir komputasi, pemecahan masalah, eksperimen, berpikir kritis dan analisis, meningkatkan kreativitas dan ekspresi, serta beradaptasi dengan tantangan baru yang merupakan keterampilan abad 21 untuk anak dan siswa di SD, SMP dan SMA. Aplikasi edukasi yang dapat digunakan ini merupakan jenis aplikasi Open Source Software dan Freeware berbasis desktop, aplikasi berbasis web, dan aplikasi berbasis mobile yang dapat dipergunakan dengan gratis[3]. Aplikasi edukasi belajar bahasa pemrograman merupakan bahasa pemrograman yang awalnya dibuat utamanya sebagai instrumen pembelajaran dan tujuan pendidikan, bukan sebagai alat bantu pembuatan aplikasi yang sesungguhnya. Namun, keunggulan beberapa aplikasi edukasi pilihan ini adalah dapat digunakan untuk membuat aplikasi sesungguhnya yang handal, karena sebenarnya beberapa aplikasi ini adalah pembuat aplikasi sesungguhnya tetapi dengan cara yang cepat dan mudah.

Terdapat beberapa aplikasi edukasi anak berbasis desktop yang dapat digunakan siswa SD, salah satunya adalah Scratch. Scratchadalah bahasa pemrograman bebas yang dapat digunakan membuat cerita interaktif, animasi, game, musik, karya seni, dan aplikasi presentasi sendiri dengan mudah [4]. Scratch dapat membantu anak-anak untuk berpikir kreatif, dan sistematis. Scratch termasuk bahasa pemrograman berorientasi objek, dan disediakan gratis (bukan proprietary software) tersedia versi online dan offline (bisa diinstal di komputer tanpa harus terhubung internet), dan bisa jalan di Windows, Linux dan MacOS. Fokus Scratch adalah membuat produk multimedia, dan membagikannya di komunitas online besar dan aktif yang dipandu oleh situs web proyek. Hal ini dimaksudkan untuk memungkinkan dan mengembangkan kreativitas anak, tapi juga mengenalkannya pada pemrograman, dengan cara yang menyenangkan [5].

Konsep aplikasi edukasi Scratch adalah konsep menyusun blok-blok perintah (visual). Siswa dapat memprogram dengan menyusun blok-blok berisi perintah (disebut blocks) seperti bergerak, bersuara, atau berinteraksi ketika suatu tombol keyboard ditekan. Scratch diperuntukkan utamanya bagi anak-anak usia 8-16 tahun, namun dapat digunakan untuk anak TK dan siswa SD-SMA. Siswa dapat memprogram dan berbagi media interaktif seperti cerita, game, animasi dan aplikasi presentasi dengan orang-orang dari seluruh dunia. Siswa belajar untuk berpikir kreatif, bekerja sama, dan berpikir komputasi. Dan bagusnya lagi Scratch juga sudah mendukung antarmuka berbahasa Indonesia.

Scratch sebagai bahasa pemrograman visual yang populer menawarkan sejumlah kemudahan dan fitur yang menarik bagi para pemula dalam mempelajari cara pemrograman [6]. Scratch membantu anak-anak belajar untuk berpikir kreatif, sistematis, dalam membuatsuatu program aplikasi yang dapat bermanfaat untuk memberi dasar keahlian mereka dalam teori pemrograman.Dengan adanya pembelajaran teori pemrograman kepada anak-anak dengan menggunakan aplikasi edukasi Scratch diharapkan terjadi : 
1. Pembelajaran teori pemrograman kepada anak-anak dapat dilakukan secara mudah dan menyenangkan.

2. Pembelajaran teori pemrograman kepada anak-anak dapat mengembangkan kreatifitas mereka dalam menggunakan komputer.

3. Pembelajaran teori pemrograman kepada anak-anak dapat menjadikan sebagai pengguna aktif teknologi komputer.

\section{METODE}

Metode yang dilakukan dalam kegiatan pengabdian kepada masyarakat di Sekolah Dasar Negeri Model Mataram ini terdiri dari tiga tahapan, antara lain:

a. Tahap persiapan

1. Kunjungan ke sekolah yang akan diberi pembelajaran.

2. Mengidentifikasi karakter siswa yang akan diberi pembelajaran.

3. Penetapan jadwal kegiatan pembelajaran bersama guru/pimpinan sekolah tersebut.

4. Pengumpulan materi pembelajaran.

5. Pembagian materi pembelajaran pada setiap anggota pelaksana PPM

b. Tahap pelaksanaan

1. Persiapan peralatan pembelajaran.

2. Penginstallan aplikasi edukasi Scratch pada laptop siswa.

3. Pembelajaran aplikasi edukasi Scratch kepada siswa oleh setiap anggota pelaksana.

4. Latihan pemrograman menggunakan aplikasi edukasi Scratch.

5. Memberi tugas kepada siswa berkreasi membuat program menggunakan aplikasi edukasi Scratch.

\section{c. Tahap evaluasi}

1. Kunjungan ke sekolah untuk mengumpulkan hasil pekerjaan siswa berupa kreasi membuat program menggunakan aplikasi edukasi Scratch.

2. Penilaian karya siswa untuk menentukan tingkat pemahaman dan kemampuan berkreasi siswa.

3. Memberi apresiasi berupa pemberian penghargaan bagi karya-karya siswa yang terbaik dari segi penampilan dan tingkat kreatifitas

\section{HASIL DAN PEMBAHASAN}

\section{Tahap persiapan}

Sesuai dengan pendekatan/metode pelaksanaan kegiatan yang telah direncanakan maka kegiatan pengabdian pada masyarakat ini diawali dengan melakukan kunjungan ke sekolah yang akan diberi penyuluhan yaitu dengan mengunjungi Sekolah Dasar Negeri Model Mataram. Pada pertemuan tersebut, tim pelaksana menyampaikan rencana kegiatan pengabdian pada masyarakat kepada tenaga pendidik dari kelas yang akan diberi penyuluhan agar mendapatkan persetujuan terlebih dahulu.Selanjutnya dilakukan wawancara kepada tenaga pendidik kelas tersebut terkait karakter siswa di kelas tersebut. Hasil wawancara memberikan keterangan bahwa karakter siswa di sana rata-rata cukup mudah menangkap materi pelajaran di kelas sehingga memudahkan untuk memberi materi penyuluhan dengan bahasa yang lebih teknis.

Selain itu dilakukan pula pembahasan mengenai penetapan jadwal kegiatan penyuluhan bersama tenaga pendidik di kelas tersebut. Hasil pembahasan menetapkan bahwa kegiatan penyuluhan akan dilaksanakan bersamaan dengan jam pelajaran TIK di kelas tersebut. Hal ini diputuskan untuk efisiensi penggunaan waktu belajar dari siswa dan tidak mengganggu mata pelajaran lainnya yang tidak terkait dengan penggunaan komputer.

Persiapan selanjutnya adalah mengumpulkan materi yang akan diberikan pada saat penyuluhan. Materi diambil dari buku yang terdapat di internet yang membahas tentang aplikasi edukasi Scratch. Setelah materi terkumpul, anggota tim berkumpul dan mendiskusikan pembagian materi penyuluhan yang akan disampaikan masing-masing anggota pada saat penyuluhan. 


\section{Tahap pelaksanaan}

Pada hari yang telah disepakati antara tim pelaksana dengan pihak sekolah, akhirnya kegiatan penyuluhan ini dilaksanakan di salah satu kelas/ruang di Sekolah Dasar Negeri Model Mataram dengan dihadiri oleh siswa kelas IV.Tim pelaksana kegiatan pengabdian pada masyarakat hadir di sekolah tersebut pada pukul 09.00 wita sebagaimana yang telah direncanakan sebelumnya. Setelah semua peralatan disiapkan antara lain LCD projector, laptop penyuluh dan laptop seluruh siswa, akhirnya acara dimulai pada pukul 09.30 Wita.

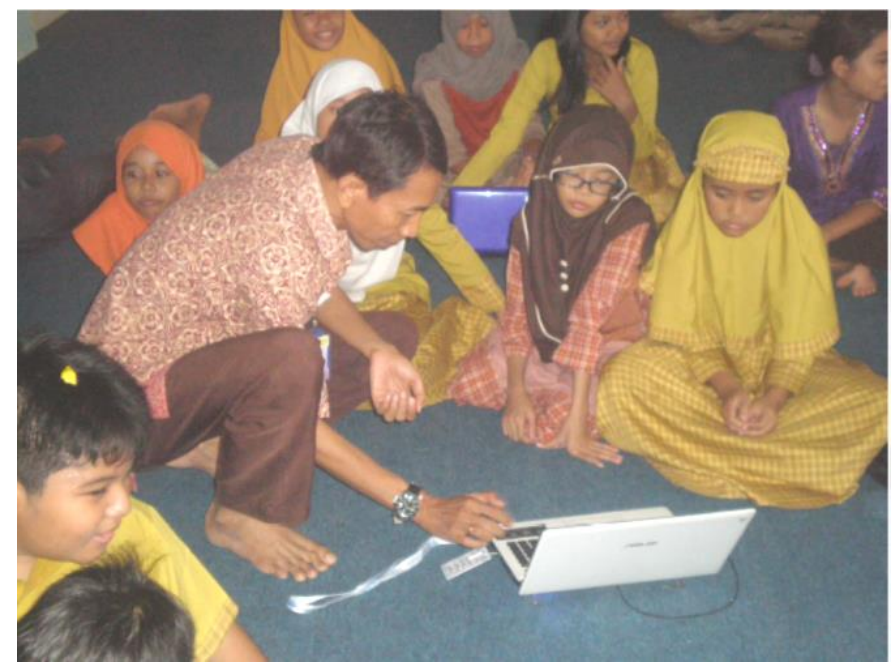

Gambar 1. Penginstallan aplikasi edukasi Scratch sebelum kegiatan penyuluhan

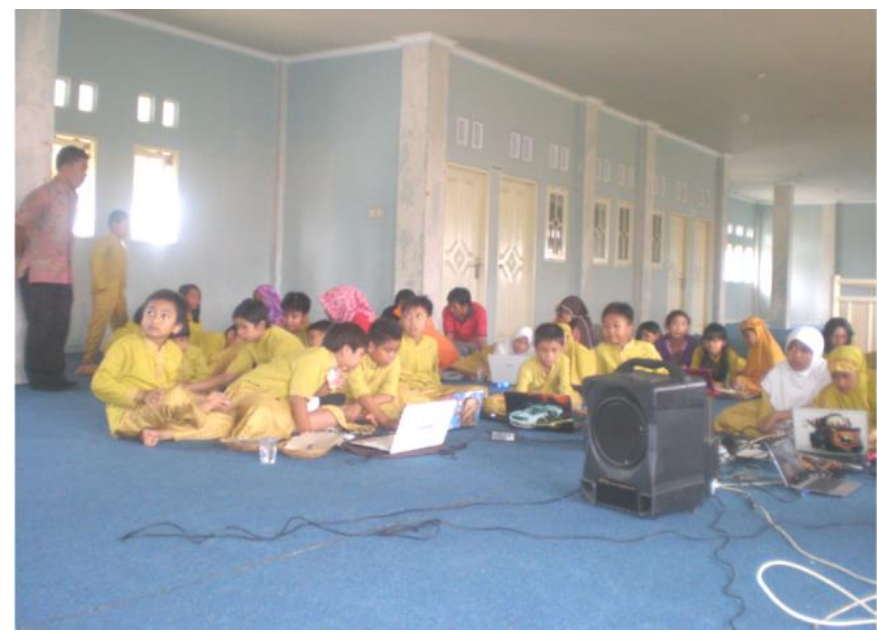

Gambar 2. Sambutan dari tenaga pendidik kelas IV SDN Model Mataram

Kegiatan diawali dengan penginstallan aplikasi edukasi Scratch pada laptop siswa sebagaimana ditunjukkan pada Gambar 1 dan dilanjutkan dengan sambutan dari tenaga pendidik kelas tersebut terkait dengan kehadiran tim pelaksana kegiatan pengabdian pada masyarakat dari Jurusan Teknik Elektro Fakultas Teknik Universitas Mataram dan kegiatan penyuluhan yang akan dilaksanakan sebagaiman ditunjukkan pada Gambar 2. Acara selanjutnya adalah sambutan dari tim pelaksana kegiatan pengabdian pada masyarakat dari Jurusan Teknik elektro Fakultas Teknik Universitas Mataram terkait dengan ucapan terima kasih atas kesediaan sekolah tersebut untuk menerima kehadiran tim dan memperkenalkan personalia tim berikut materi yang akan disampaikan sebagaimana ditunjukkan pada Gambar 3. 


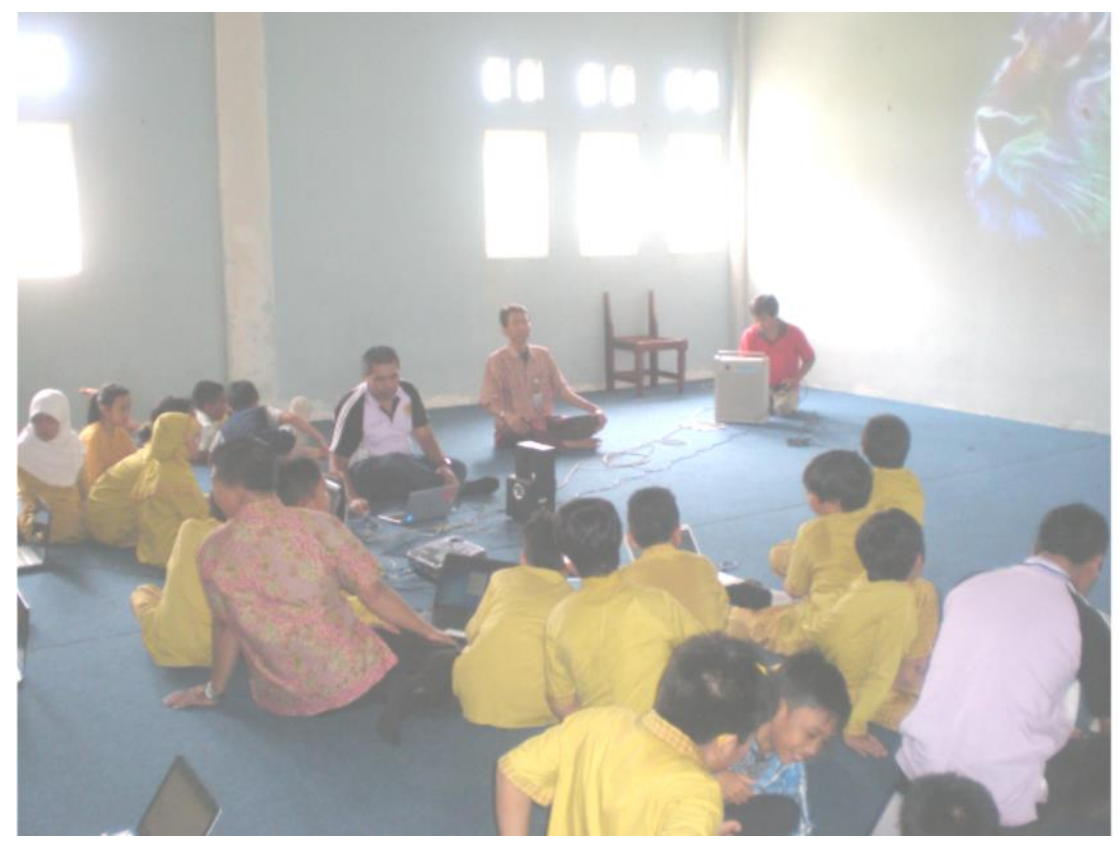

Gambar 3. Sambutan dari tim pelaksana

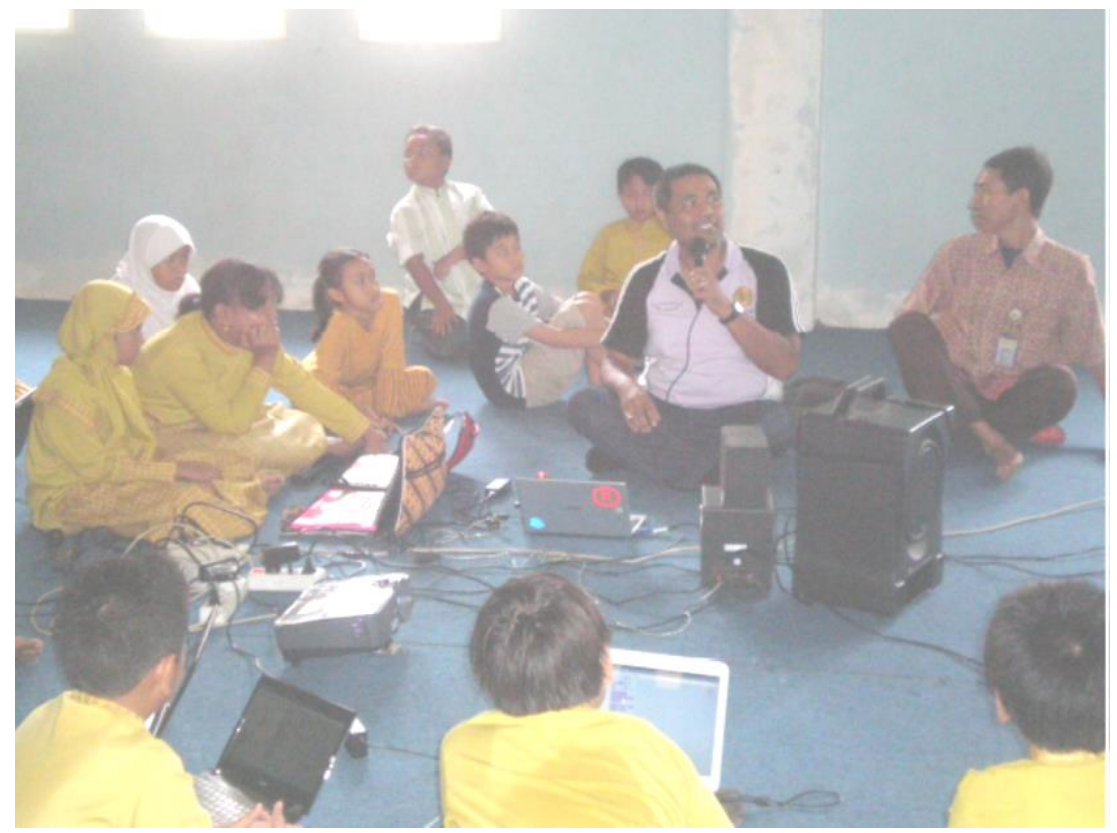

Gambar 4. Pemateri pertama sedangkan menyampaikan materi

Pada Gambar 4 ditunjukkan penyuluhan dimulai oleh pemateri pertama yaitu I Made Budi Suksmadana. Pemateri pertama ini menyampaikan materi tentang Pengantar Belajar Pemrogramandengan Scratchyang isinya berupa pengenalan tentang apa itu Scratch sebagaimana ditunjukkan pada Gambar 5. Penyuluhan selanjutnya dilaksanakan oleh pemateri kedua yaitu Ida Bagus Fery Citarsa yang menyampaikan materi tentang Lingkungan Scratch dan Saatnya Beraksi 1,2, dan 3 yang isinya berupa latihan pemrograman menggunakan Scratch sebagaimana ditunjukkan pada Gambar 6. Penyuluhan selanjutnya dilaksanakan oleh pemateri ketiga yaitu I Nyoman Wahyu Satiawan, yang menyampaikan materi tentang Saatnya Beraksi 4,5, dan 6 yang isinya berupa latihan pemrograman menggunakan Scratch sebagaimana ditunjukkan pada Gambar 7. Penyuluhan selanjutnya dilaksanakan oleh pemateri keempat yaitu I Ketut Wiryajati yang menyampaikan materi tentang Saatnya Beraksi 7,8, dan 9 yang isinya berupa latihan pemrograman menggunakan Scratch sebagaimana ditunjukkan 
pada Gambar 8. Penyuluhan selanjutnya dilaksanakan oleh pemateri kelima yaitu Sabar Nababan yang menyampaikan materi tentang Saatnya Beraksi 10, 11, dan 12 yang isinya berupa latihan pemrograman menggunakan Scratch sebagaimana ditunjukkan pada Gambar 9.

Siswa mendengarkan dengan seksama semua materi yang disampaikan oleh para pemateri. Siswa juga diminta mengerjakan semua latihan pemrograman menggunakan Scratch yang diberikan dalam materi tentang Saatnya Beraksi 1 sampai 12 . Tim penyuluh yang tidak sedang menyampaikan materi berkeliling untuk membantu siswa yang mengalami kesulitan dalam mengerjakan latihan-latihan tersebut.

\begin{tabular}{|c|c|}
\hline $\begin{array}{l}\text { Belajar Pemrograman Dengan } \\
\text { SCRATCH }\end{array}$ & $\begin{array}{l}\text { Pemrograman } \\
\text { - Adalah proses menulis, menguji, memperbaiki (debug), } \\
\text { - Kode program dapat ditulis dalam berbagai bahasa } \\
\text { pemrograman } \\
\text { - Tujuan dari pemrograman adalah untuk membuat } \\
\text { suatu program yang dapat melakukan suatu } \\
\text { perhitungan atau 'pekerjaan' sesuai dengan keinginan } \\
\text { si pemrogram (programmer) } \\
\text { - Untuk dapat melakukan pemrograman, diperlukan } \\
\text { keterampilan dalam algoritma, logika, bahasa } \\
\text { pemrograman, dan di banyak kasus juga perlu } \\
\text { pengetahuan-pengetahuan lain seperti matematika. }\end{array}$ \\
\hline $\begin{array}{l}\text { Algoritma } \\
\text { Adangkah prosedur langkah-demi } \\
\text { menyelesaikan suatu masalah } \\
\text { (misal untuk menentukan } \\
\text { sebuah bilangan genap maka } \\
\text { langkah yg hrs dilakukan adalah } \\
\text { membagi bil. tersebut dengan 2, } \\
\text { kemudian cek hasil bagi dan } \\
\text { sisanya, jika sisanya 0 maka bil. } \\
\text { tersebut adalah bil. Genap) } \\
\text { Biasanya algoritma } \\
\text { digambarkan dengan flowchart }\end{array}$ & $\begin{array}{l}\text { Pemrograman SCARTCH } \\
\text { pemula untuk membuat program tanpa harus } \\
\text { belajar menulis sintaksis yang benar. } \\
\text { Bahasa pemrograman ini dibuat oleh MIT } \\
\text { Media Lab dari Massachusetts Institute of } \\
\text { Technology. } \\
\text { Dengan Scratch, pengguna dapat membuat } \\
\text { animasi, permainan dan lain-lain. } \\
\end{array}$ \\
\hline
\end{tabular}

Gambar 5. Materi tentang Pengantar Belajar Pemrograman dengan Scratch[4]

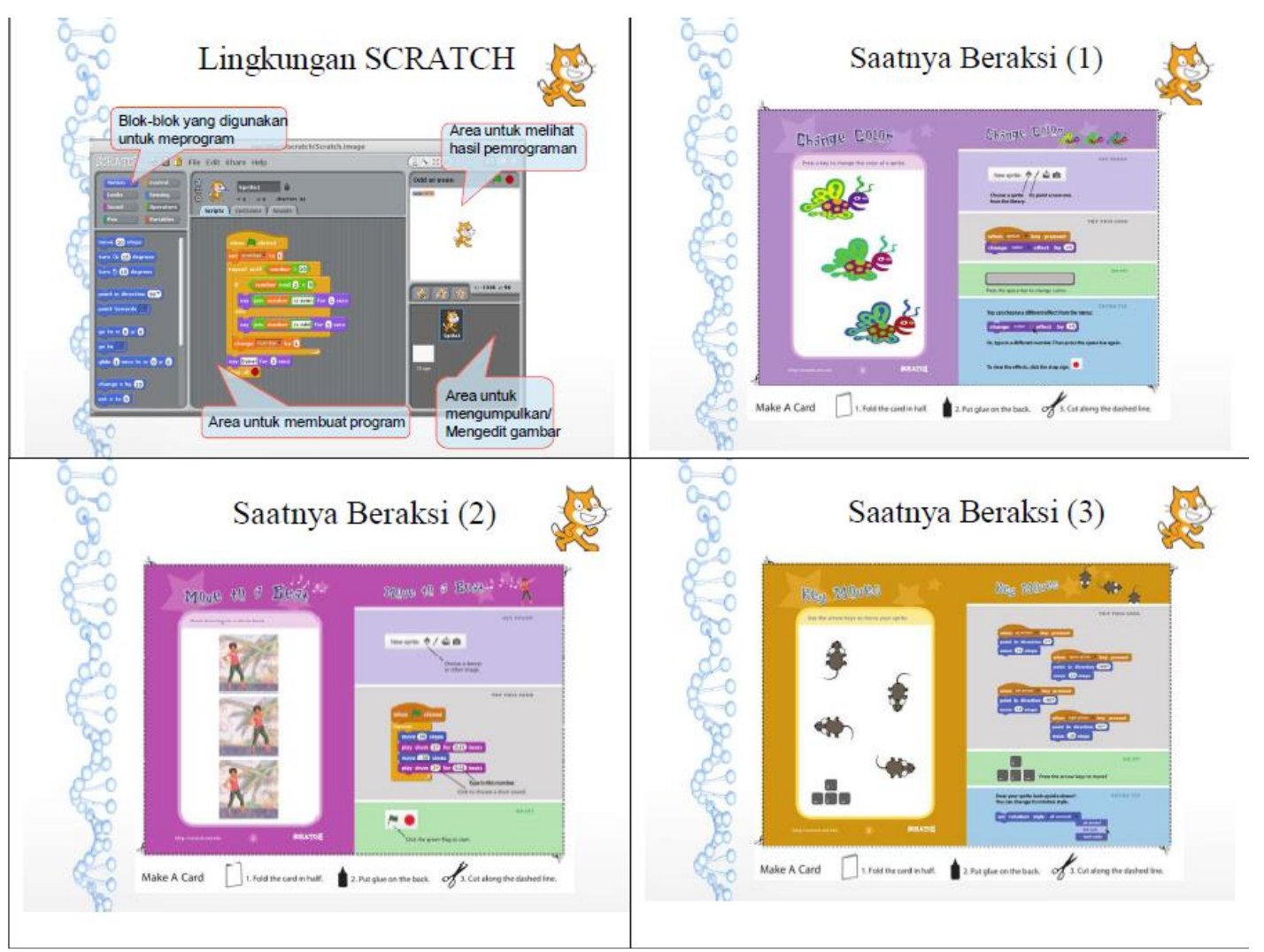


Gambar 6. Materi tentang Lingkungan Scratchdan Saatnya Beraksi 1,2 dan 3 [4]

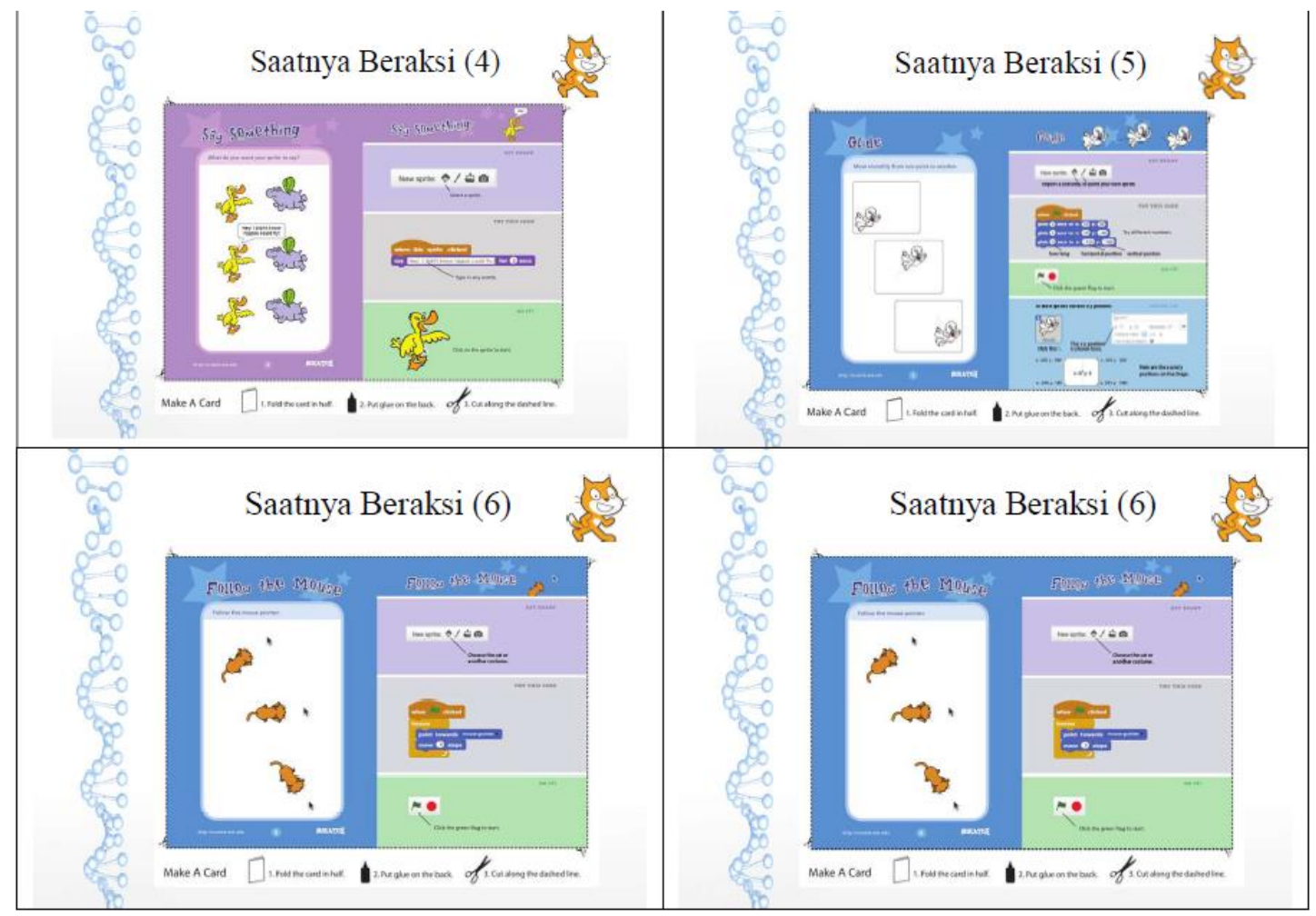

Gambar 7. Materi tentang Saatnya Beraksi 4,5 dan 6[4]

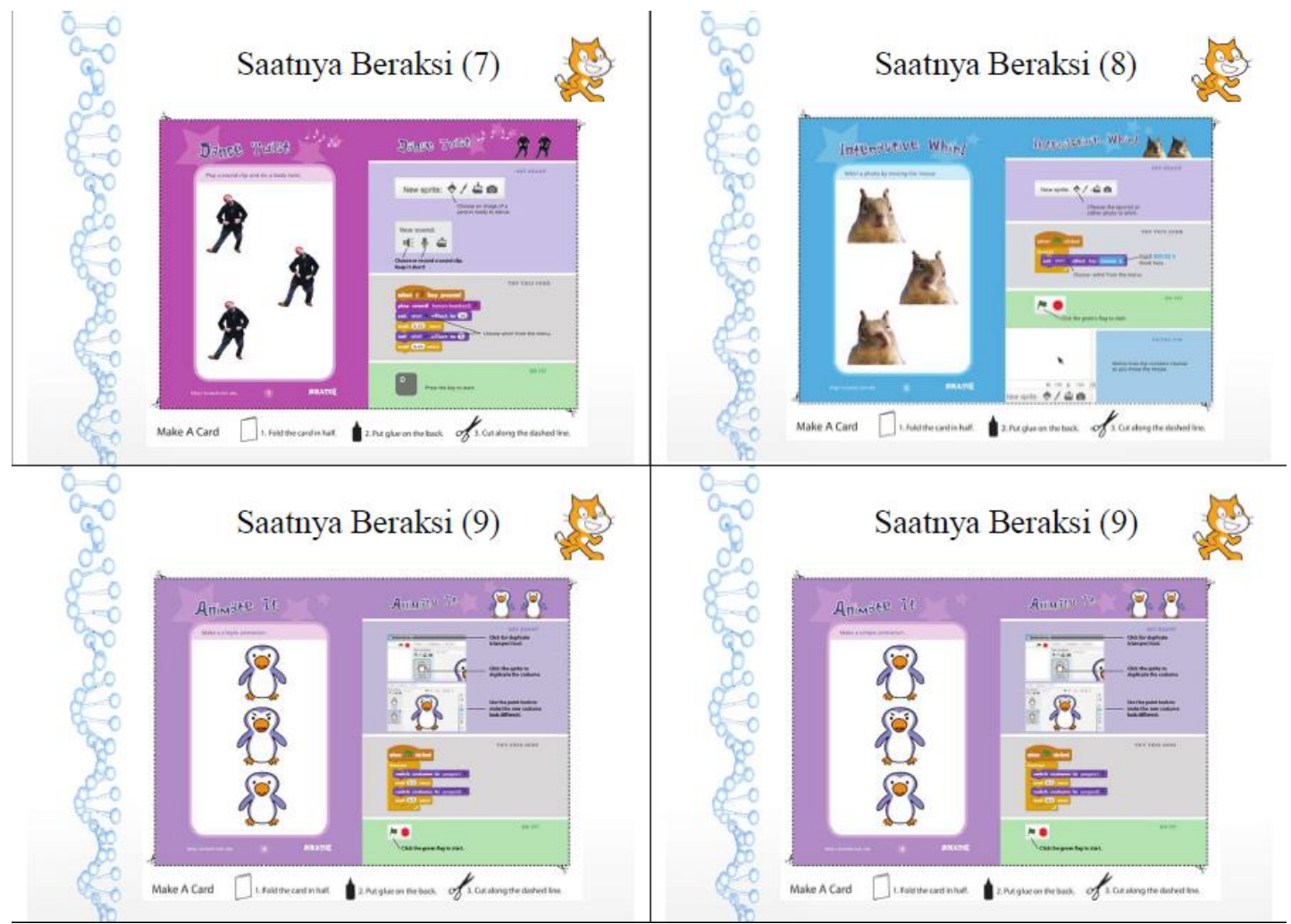

Gambar 8. Materi tentang Saatnya Beraksi 7,8 dan 9[4] 


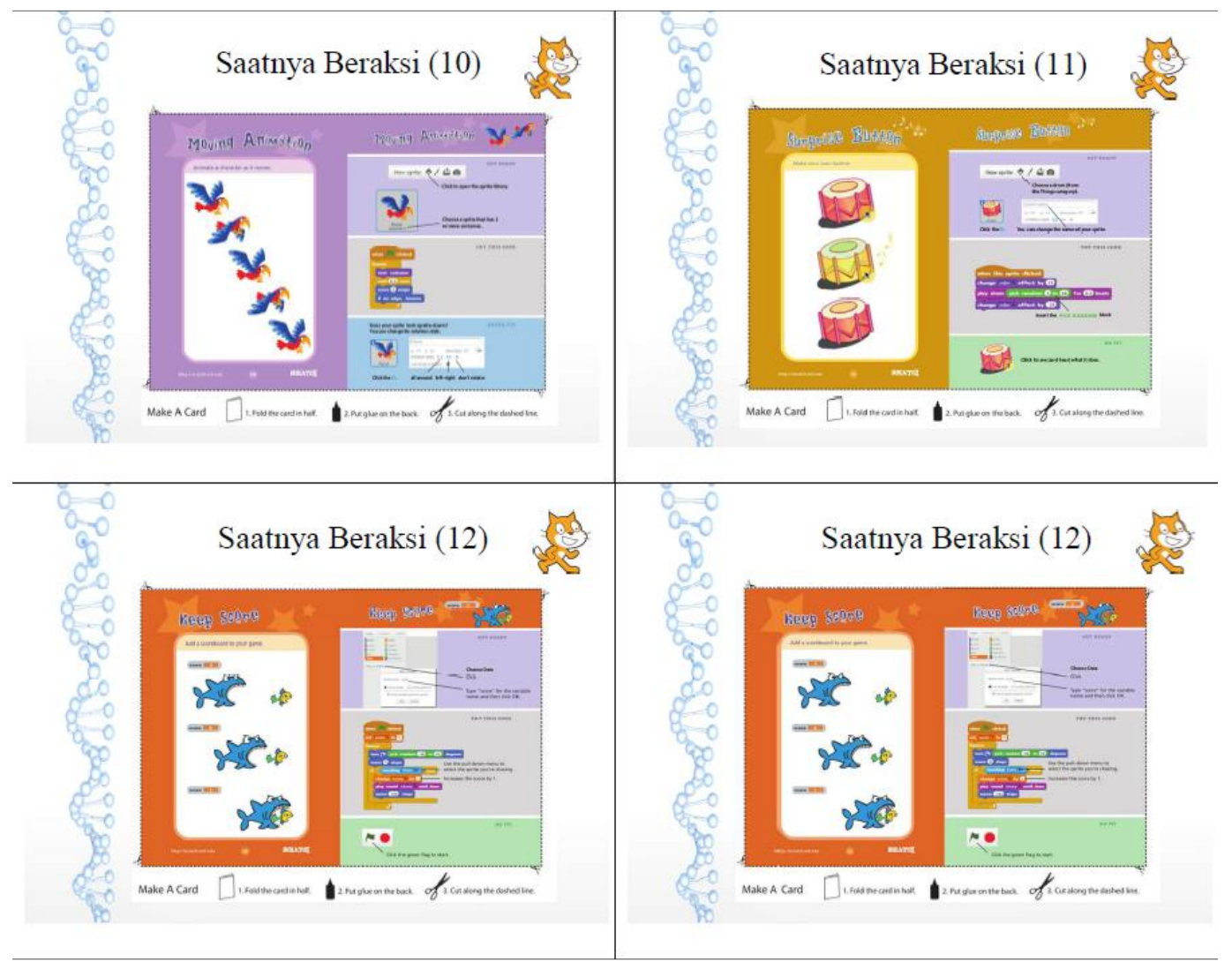

Gambar 9. Materi tentang Saatnya Beraksi 10,11 dan 12 [4]

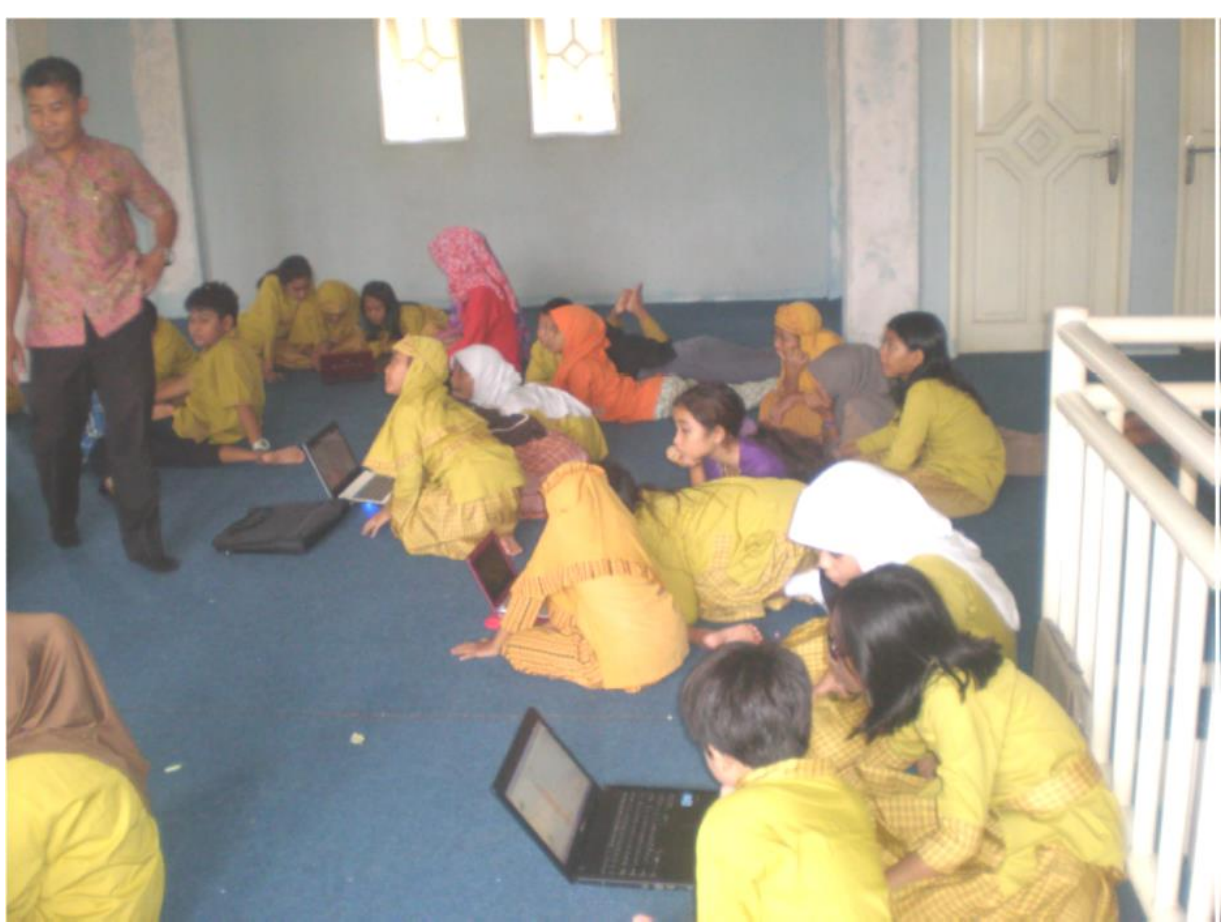

Gambar 10. Siswa mengerjakan latihan yang diberikan dalam materi

Setelah semua anggota tim pelaksana kegiatan pengabdian pada masyarakat menyampaikan materinya masing-masing, maka acara selanjutnya adalah sesi tanya jawab antara peserta penyuluhan dengan tim pelaksana terkait dengan isi materi penyuluhan yang 
baru saja disampaikan.Setelah sesi tanya jawab berakhir, akhirnya kegiatan dilanjutkan dengan memberi tugas kepada siswa berkreasi membuat program menggunakan aplikasi edukasi Scratch. Sebagai penutup acara, disampaikanlah ucapan terima kasih dari ketua tim pelaksana kepada tenaga pendidik dan siswa kelas IV Sekolah Dasar Negeri Model Mataram.

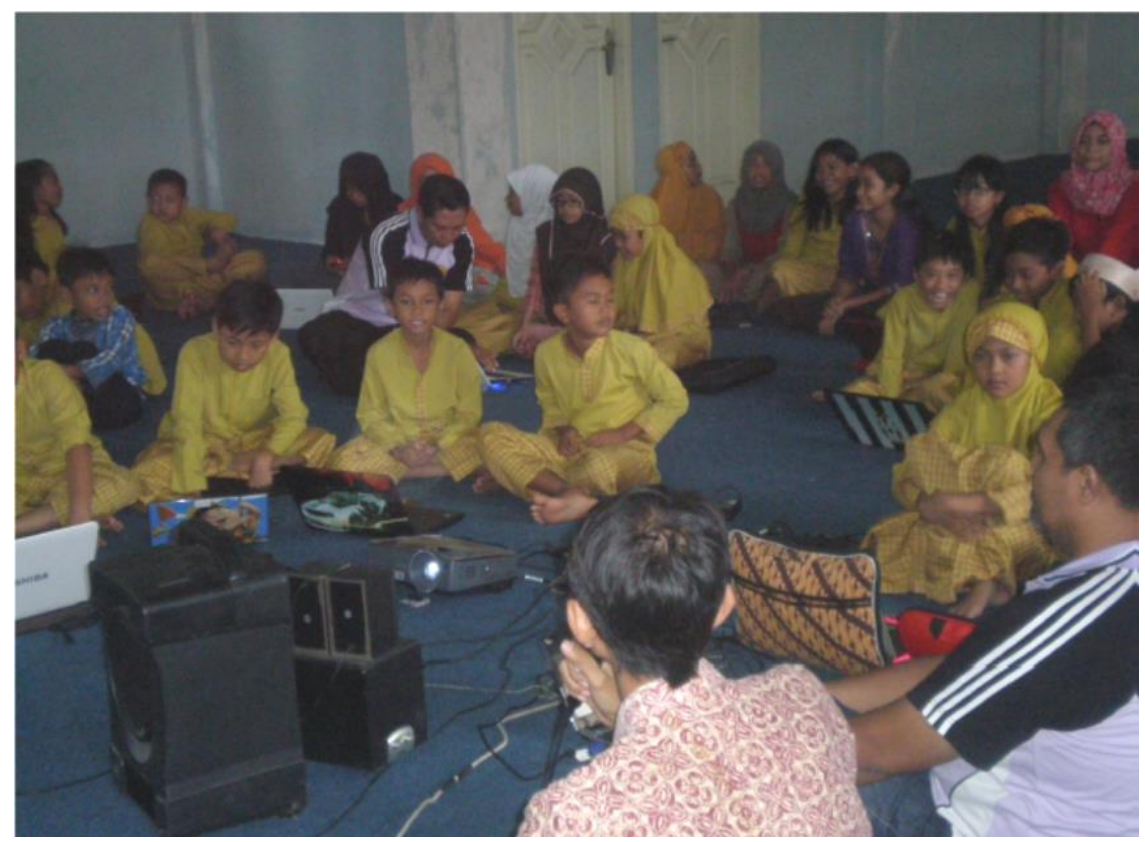

Gambar 11. Sesi tanya jawab pemateri dengan peserta

\section{Tahap evaluasi}

Beberapa saat setelah hari pelaksanaan kegiatan penyuluhan, tim pelaksana kembali mengadakan kunjungan ke Sekolah Dasar Negeri Model Mataram untuk mengetahui hasil penyuluhan terkait dengan tugas yang diberikan kepada siswa dengan berkreasi membuat program menggunakan aplikasi edukasi Scratch. Berdasarkan hasil tugas yang dikumpulkan, dilakukan penilaian karya siswa untuk menentukan tingkat pemahaman dan kemampuan berkreasi siswa. Diperoleh hasil bahwa sebagian besar siswa telah mampu mengaplikasikan hasil penyuluhan yang telah diberikan sebelumnya, terkait penggunaan aplikasi edukasi Scratch. Mereka telah berhasil mencoba untuk menerapkan petunjuk-petunjuk yang telah diberikan tim pelaksana pada saat penyuluhan dalam menggunakan program Scratch dalam hasil kreasi mereka. Dilakukan pula pemberian apresiasi berupa penghargaan bagi karya-karya siswa yang terbaik dari segi penampilan dan tingkat kreatifitas.

\section{KESIMPULAN}

Berdasarkan hasil evaluasi kegiatan pengabdian kepada masyarakat yang telah dilaksanakan di atas, dapat disimpulkan hal-hal sebagai berikut:

1. Penyuluhan ini telah memberikan pengetahuan kepada siswa kelas IV Sekolah Dasar Negeri Model Matarammengenai teori pemrograman komputer menggunakan perangkat lunak Scratch.

2. Beberapa informasi yang diberikan merupakan hal baru bagi siswa peserta penyuluhan di Sekolah Dasar Negeri Model Mataram.

3. Berdasarkan hasil evaluasi kegiatan yaitu dengan melakukan penilaian terhadap hasil kreasi para siswa kelas IV Sekolah Dasar Negeri Model Mataram diketahui bahwa para siswa tersebut telah cukup memahamimengenai teori pemrograman komputer menggunakan perangkat lunak Scratch.

4. Rekomendasi agar kegiatan seperti ini lebih banyak dilakukan di sekolah-sekolah dasar lainnya agar lebih banyak lagi siswa SD yang mengenal teori pemrograman komputer sejak usia dini. 


\section{UCAPAN TERIMA KASIH}

Penulis mengucapkan terima kasih kepada Lembaga Penelitian dan Pengabdian Pada Masyarakat dan Jurusan Teknik Elektro Fakultas Teknik Universitas Mataram yang telah memberi dukungan berupa fasilitas pendidikan. Demikian pula kepada pihak Pimpinan, Tenaga Pendidik serta Siswa Kelas IV Sekolah Dasar Negeri Model Mataram yang telah menjadi mitra dalam pelaksanaan kegiatan pengabdian pada masyarakat ini.

\section{REFERENSI}

[1] Sufa, F.F. (2015). Mengembangkan kognisi anak usia dini melalui pembelajaran computer. Widya Wacana: Jurnal IImiah, 10(1), 62-74. Diperoleh melalui http://ejurnal.unisri.ac.id/index.php/widyawacana/article/view/991.

[2] Lutfina, E. \& Wardhani, A.K. (2020). Pengenalan dan pelatihan pemrograman berbasis blok bagi anak. Magistrorum Et Scholarium: Jurnal Pengabdian Masyarakat, 01(1), 107-111. Doi:10.24246/jms.v1i12020p107-111.

[3] Milonovich, B. (2013). Scratch Cookbook. Birmingham: Packt Publishing.

[4] Badger, M. (2014). Scratch 2.0 Beginner's Guide Second Edition. Birmingham - Mumbai: Packt Publishing.

[4] Pratama, A. (2018). Pengaruh pengajaran pemrogaman animasi melalui aplikasi scratch pada kemampuan pemecahan masalah. JOINED Journal Of Informatics Education, 1(1), 107-111. Doi: 10.31331/joined.v1i1.613.

[5] Hansun, S. (2014). Rancang bangun permainan interaktif dengan scratch. ULTIMATICS, 6(1), 40-45. Diperoleh melalui https://ejournals.umn.ac.id/index.php/TI/issue/view/11. 